medRxiv preprint doi: https://doi.org/10.1101/2021.04.12.21255337; this version posted April 19, 2021. The copyright holder for this preprint (which was not certified by peer review) is the author/funder, who has granted medRxiv a license to display the preprint in perpetuity.

It is made available under a CC-BY-NC 4.0 International license .

\title{
Rapid, inexpensive methods for exploring SARS CoV-2 D614G mutation
}

Sirwan M.A. Al-Jaf ${ }^{1,2}$, Sherko Subhan Niranji ${ }^{1,2, *}$ and Zana Hameed Mahmood ${ }^{3,4}$

1- Department of Biology, College of Education, University of Garmian, Kurdistan Region, Iraq

2- Coronavirus Research and Identification Lab., University of Garmian, Kurdistan Region, Iraq

3- Molecular Diagnostic Laboratory, Sulaimani Veterinary Directorate, Sulaimani, Kurdistan, Iraq

4- Institute of Infection, Veterinary and Ecological Sciences, University of Liverpool, UK

*Corresponding author: Department of Biology, College of Education, University of Garmian, Berdasur campus, Kalar, 46021, Kurdistan Regional Government, Iraq. Email: sherko.subhan@garmian.edu.krd. Tel: 009647707798899.

\section{Abstract}

A common mutation has occurred in the spike protein of severe acute respiratory syndrome coronavirus 2 (SARS CoV-2), known as D614G (A23403G). There are discrepancies in impacting of this mutation on the virus's infectivity, and the whole genome sequencings are expensive and time-consuming. This study aims to develop three fast economical assays for prompt identifications of the D614G mutation including Taqman probe-based real-time reverse transcriptase polymerase chain reaction ( $r R T$ PCR), an amplification refractory mutation system (ARMS) RT and restriction fragment length polymorphism (RFLP), in nasopharyngeal swab samples. Both rRT and ARMS data showed G614 mutant indicated by presence of HEX probe and 176bp, respectively. Additionally, the results of the RFLP data and DNA sequencings confirmed the prevalence of G614 mutant. These methods will be important, in epidemiological, reinfections and zoonotic aspects, through detecting the G614 mutant in retro-perspective samples to track its origins and future re-emergence of D614 wild type.

Keywords: SARS CoV-2, D614G, real-time PCR, ARMS, RFLP, mutation

\section{Abbreviations}

SARS CoV-2: severe acute respiratory syndrome coronavirus 2

D614G: Aspartate 614 mutated to Glycine

ARMS: amplification refractory mutation system RT

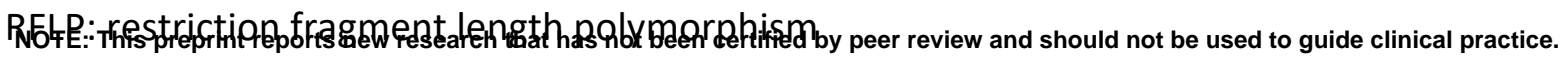


medRxiv preprint doi: https://doi.org/10.1101/2021.04.12.21255337; this version posted April 19, 2021. The copyright holder for this preprint (which was not certified by peer review) is the author/funder, who has granted medRxiv a license to display the preprint in perpetuity. It is made available under a CC-BY-NC 4.0 International license .

\section{Introduction}

Since its first emergence in Wuhan, China in late December 2019, severe acute respiratory syndrome coronavirus 2 (SARS CoV-2) which leads to coronavirus disease 2019 (Covid-19), has been considered as pandemic since March 2020 by World Health Organisation (WHO) and it has caused approximately 107.8 million global infections and 2.37 million deaths by 12 February 2021 (COVID-19 Dashboard by the Centre for Systems Science and Engineering (CSSE) at Johns Hopkins University (JHU) https://coronavirus.jhu.edu/map.html). The genome of SARS CoV-2 contains several genes encoding structural proteins such as spike (S), envelope (E), membrane (M), and nucleocapsid (N) (Ahmadpour et al., 2020). SARS CoV-2 interacts with angiotensin-converting enzyme 2 (ACE2) of human cells through its spike proteins, spike 1 (S1) and spike 2 (S2) (Walls et al., 2020), which are cleaved, by human type II transmembrane serine protease (TMPRSS2) and furin, to facilitate the viral envelope fusion with the targeted human cell membrane (Ahmadpour et al., 2020; Walls et al., 2020). It is worth mentioning that S1 protein has three main domains: C-terminal domain (CTD), receptor-binding domain (RBD) which binds to human ACE2, and N-terminal domain (NTD) (Ahmadpour et al., 2020).

However, SARS CoV-2 has proofread mechanisms for correcting its RNA replication errors, nevertheless, mutations occur in its genome leading to an increase in viral survival adaptations (Pachetti et al., 2020; Phan, 2020; Robson et al., 2020; Romano et al., 2020). One of the most common mutations occurred, since its emergence, has been recognized as D614G (A23403) at amino acid number 614 in the spike protein sequence (nucleotide sequence number 23403) of the reference Wuhan SARS CoV-2 genome, when nucleotide A in GAT encoding aspartate residue (D) altered to G creating GGT, a codon for glycine (Badua et al., 2020). The D614G mutation is located in the NTD of S1 that lies between RBD and S2 near the cleavage site (Bhattacharyya et al., 2020), where both S1 and S2 are cleaved by TMPRSS2 and furin (Ahmadpour et al., 2020; Walls et al., 2020). Therefore, this mutation may enhance the viral infectivity of SARS CoV-2 by increasing the attachment capability of the RBD to human ACE2 via decreasing interactions between S1 and S2 (Gupta et al., 2020).

Since the emergence of the SARS CoV-2 D614G mutation, tracing back to January 2020 from China to Europe (Xu et al., 2020), and its current highly prevalence in all continents of the world (Bhattacharyya et al., 2020; Gómez-Carballa et al., 2020), there have been controversial 
medRxiv preprint doi: https://doi.org/10.1101/2021.04.12.21255337; this version posted April 19, 2021. The copyright holder for this preprint (which was not certified by peer review) is the author/funder, who has granted medRxiv a license to display the preprint in perpetuity. It is made available under a CC-BY-NC 4.0 International license .

studies on impacts of this single nucleotide variation (SNV), D614G, on the viral survival fitness (Isabel et al., 2020; Kim et al., 2020; Omotuyi et al., 2020; Yong Zhang et al., 2020), immunogenicity and antigenic epitopes (Gupta et al., 2020; Hernández-Huerta et al., 2020; Islam et al., 2020; Kim et al., 2020; Koyama et al., 2020; Saha et al., 2020; To et al., 2020), antibody neutralising sensitivity (Garcia-Beltran et al., 2020; Goldman et al., 2020; Hu et al., 2020; Klumpp-Thomas et al., 2020; Li et al., 2020; Mansbach et al., 2020; Plante et al., 2020), infectivity (Daniloski et al., 2020; Hu et al., 2020; Korber et al., 2020; Li et al., 2020), transmission (van Dorp et al., 2020) and fatality (Hernández-Huerta 2020). The studies have mainly focused on bioinformatic simulation models, and sequence alignments comparing with other coronavirus genomes with the available SARS CoV-2 whole viral genome sequences. They predicted spike protein destabilizing effect of the D614G mutation, leading to rapid S1 detachment with S2 causing more ACE2 attachments. Few studies have conducted investigations of D614G mutation on in vitro viral pseudotype infected cells (Daniloski et al., 2020; Hou et al., 2020; Hu et al., 2020; Korber et al., 2020; Li et al., 2020; Wang et al., 2020), laboratory animal models (Plante et al., 2020), and infected populations, suggesting increases in infectivity, viral loads (Korber et al., 2020; Yurkovetskiy et al., 2020; L. Zhang et al., 2020), and fatality (Hernández-Huerta et al., 2020). Overall, data indicated the viral adaptability to human cells as a result of D614G mutation. However, few studies have considered this single mutation outside RBD as a consequence of random mutations (Dearlove et al., 2020; van Dorp et al., 2020; Grubaugh et al., 2020; Isabel et al., 2020). Thus, these discrepancies should be elucidated to see whether the mutation is due to viral fitness or a random process (Korber et al., 2020).

On one hand, no adequate cohort clinical data have been obtainable for finding causality or even associations between this mutation and Covid-19 patients' severity. On the other hand, sufficient whole genome sequences might be available only in countries with highly developed genome services. However, whole genome sequencings are expensive and timeconsuming. Moreover, there should have been plethora of SARS CoV-2 positive nasopharyngeal samples stored in developing countries without being sequenced due to lack of whole genome sequence facilities. Thus, retro-perspective studies are required to discover the origin of the virus imported into those countries. 
medRxiv preprint doi: https://doi.org/10.1101/2021.04.12.21255337; this version posted April 19, 2021. The copyright holder for this preprint (which was not certified by peer review) is the author/funder, who has granted medRxiv a license to display the preprint in perpetuity.

It is made available under a CC-BY-NC 4.0 International license .

Therefore, developing inexpensive and rapid methods for identifying SNVs, such as D614G, are essential for tracking this variant by epidemiologists, molecular virologists or immunologist collaborating with clinicians to compare Covid-19 patients with SARS CoV-2 D614 and G614 variants. Previous study mistakenly developed an RFLP method for identifying another mutation at residue 615 of the spike protein (Hashemi et al., 2020), but not D614G as commented by Niranji and Al-Jaf (Niranji and Al-Jaf, 2021). Recent study highlighted the necessity of SARS CoV-2 D614G mutant using biosensing and restriction enzyme methods including $\mathrm{Bts} \mathrm{Cl}$ endonuclease which can cleave the wild type D614 but do not cut G614 mutant (Yang Zhang et al., 2020).

Therefore, the purpose of this study is to develop three various methods such as Taqman probe based rRT PCR, ARMS and RFLP to detect SARS CoV-2 D614G mutation in clinical nasal swab samples taken from Covid-19 patients. Furthermore, DNA sequencings were used for approving the validity of the methods.

\section{Materials and methods}

\subsection{Sample collection and study area}

Three (3) $\mathrm{ml}$ viral transport medium (VTM) containing nasopharyngeal swab samples were collected in Covid-19 clinically suspected individuals $(n=67)$ at Coronavirus Research and Identification Lab in the University of Garmian in Kalar town, Sulaymaniyah province, Kurdistan region of Iraq from June to October 2020. The VTM samples were preserved on ice or $4^{\circ} \mathrm{C}$ or $-85^{\circ} \mathrm{C}$ until viral nucleic acids were extracted. Written consent forms were taken from the covid-19 suspected persons and the study was ethically approved by an ethical committee, which is adhered to WHO Guidelines on Ethical Issues in Public Health Surveillance and to the principles of the Declaration of Helsinki, at the department of biology, University of Garmian.

\subsection{Viral RNA Extraction}

Sample processing was handled according to WHO standards under biological safety Level 2 using personal protection equipment (PPE) and biological safety cabinet (Labconco, Kansas City, MO, USA). Total viral RNA was extracted from the VTM preserved nasal swab samples using AddPrep Viral Nucleic Acid Extraction Kit (AddBio, Korea). According to the manufacturer's instructions, $200 \mu$ l of the VTM stored samples mixed with $350 \mu$ l lysis buffer 
medRxiv preprint doi: https://doi.org/10.1101/2021.04.12.21255337; this version posted April 19, 2021. The copyright holder for this preprint (which was not certified by peer review) is the author/funder, who has granted medRxiv a license to display the preprint in perpetuity.

It is made available under a CC-BY-NC 4.0 International license .

and $3.5 \mu \mathrm{l} \beta$-mercaptoethanol (14.2M) in a $1.5 \mathrm{ml}$ microcentrifuge tube. After 10 minutes of incubating the lysed mixture, $150 \mu$ of Isopropanol was added and this was followed by two successive washing steps, using $500 \mu$ l washing 1 and 2 solutions in a spin column, centrifuged for 13,000 rpm for 1 minute. Finally, the bound RNA was eluted with $50 \mu$ l elution buffer and the purified RNA samples were kept at $4^{\circ} \mathrm{C}$ for short-term storage or $-85^{\circ} \mathrm{C}$ deep freeze for long period preservations.

\subsection{Detection of SARS CoV-2 RNA by rRT PCR}

The RNA extracted samples were inspected for SARS CoV-2 using genesig ${ }^{\circledR}$ Real-Time PCR assay (PrimerdesignTM Ltd, UK). The assay has been originally designed to be one step rRT PCR for making both cDNA synthesis from viral RNA and amplification of the cDNA using primer-probes, specific for SARS CoV-2 RdRp, developed in a single-step reaction. According to the manufacturer's instructions, a mixture of $10 \mu$ l Oasig ${ }^{\mathrm{TM}}$ OneStep $2 \mathrm{X}$ RT-qPCR master mix and $2 \mu \mathrm{l}$ primer-probe mix was prepared. The prepared RT qPCR mixture was mixed with either $8 \mu$ I RNA, negative or positive controls, amplified using CFX Connect Real-Time PCR Detection System (Bio-Rad, Germany) at the following amplification programs: reverse transcription at $55^{\circ} \mathrm{C}$ for 10 minutes, initial denaturation at $95^{\circ} \mathrm{C}$ for 2 minutes, followed by 50 cycles of denaturation at $95^{\circ} \mathrm{C}$ for 10 seconds and annealing at $60^{\circ} \mathrm{C}$ for 60 seconds.

\subsection{Detection of SARS CoV-2 D614G mutations}

SARS CoV-2 RNA samples, identified by Gensig rRT PCR kit, with Cq values $<30$, were selected for detection of the D614G mutation by using Taqman probe-based rRT PCR, ARMS, and RFLP.

\subsubsection{Taqman probe-based $r R T P C R$}

Forward and reverse primers (D614G IN F and D614G IN R), designed to cover both sides of the D614G mutation (A23403G), with a product size of $169 \mathrm{bp}$, from the Wuhan strain (GenBank: MN908947.3), were carefully inspected using NCBI online database for checking melting temperatures, GC contents, lengths, product sizes and locations of the primers. Taqman probes including D614 D-FAM and G614 G-HEX (Macrogen, South Korea) were designed to be specific for each wildtype Adenine (A) and mutant Guanine (G), respectively, as shown in Table 1 and Figure 1B. The lyophilized primers and probes were reconstituted with RNase/DNase Free Water to $100 \mu \mathrm{M}$ which was further diluted to $10 \mu \mathrm{M}$. Ten (10) $\mu \mathrm{l}$ of Addprobe rRT PCR master mix (Addbio, South Korea) was mixed with $0.5 \mu \mathrm{l}(10 \mu \mathrm{M})$ of each 
medRxiv preprint doi: https://doi.org/10.1101/2021.04.12.21255337; this version posted April 19, 2021. The copyright holder for this preprint (which was not certified by peer review) is the author/funder, who has granted medRxiv a license to display the preprint in perpetuity. It is made available under a CC-BY-NC 4.0 International license .

primer (D614G IN F and D614G IN R) and probes (D614 D-FAM and G614 G-HEX) followed by adding $8 \mu \mathrm{l}$ of RNA, giving $20 \mu \mathrm{l}$ total volume with $250 \mathrm{nM}$ final concentrations of primer probes. The $\mathrm{rRT}$ PCR reactions were performed as follow: reverse transcription at $50^{\circ} \mathrm{C}$ for 20 minutes, initial denaturation at $95^{\circ} \mathrm{C}$ for 10 minutes, followed by 50 cycles of denaturation at $95^{\circ} \mathrm{C}$ for 10 seconds, and annealing at $61^{\circ} \mathrm{C}$ for 60 seconds using CFX Connect Real-Time PCR Detection System (Bio-Rad, Germany).

\subsubsection{Amplification-refractory mutation system PCR (ARMS-PCR)}

Four primers were designed and used in a single tube multiplex reaction including D614G outer and ARMS specific primers as shown in Table 1 and Figure 1C. Outer primers, D614G Out F and D614G Out R that amplify a PCR product size of $266 \mathrm{bp}$ in which both A and G variants were located. D614G ARMS specific primers were designed as follows: D614 ARMS $\underline{A} F$ amplifies the wildtype $\underline{A}$ with the D614 Out R creating a $134 \mathrm{bp}$ PCR product size. $\underline{G} 614$ ARMS $\underline{\mathbf{G}} \mathrm{R}$ amplifies the mutant $\underline{\mathbf{G}}$ with the D614 Out F primer creating a $176 \mathrm{bp}$ PCR product (Table 1 and Figure 1C). ARMS primers were designed in a manner that the wild type $\underline{\mathbf{A}}$ nucleotide is located at the $\mathbf{3}^{\prime}$ end of the forward primer while the mutant $\mathbf{G}$ nucleotide is located at the 3 'end of the reverse primer. To reduce non-specific amplification, a nucleotide mismatch was introduced, just two nucleotides before the 3 'end of each ARMS primer. The ARMS PCR reaction mixtures were as follows: $0.5 \mu$ l of ARMS primers $(10 \mu \mathrm{M})$ added to $10 \mu$ l of Addscript RT PCR master mix (Addbio) and $8 \mu$ I RNA. The PCR program was set using conventional Lightcycler (Eppendorf, Germany) as follow: reverse transcription at $50^{\circ} \mathrm{C}$ for 20 minutes, initial denaturation at $98^{\circ} \mathrm{C}$ for 10 minutes, followed by 36 cycles of denaturation at $95^{\circ} \mathrm{C}$ for 15 seconds, annealing at $61^{\circ} \mathrm{C}$ for 45 seconds, and extension $72^{\circ} \mathrm{C}$ for 30 seconds and then a final extension at $72^{\circ} \mathrm{C}$ for 5 minutes.

\subsubsection{RFLP method for D614G variant}

This methods was developed using NEB cutter (https://nc2.neb.com/NEBcutter2/index.php). Interestingly, $\mathrm{BtsCl}$ restrictions site (5'-GGATGNN-3') was found in the wild type D614 (GㅁT) but not in G614 mutant (GGT). Thus, this enzyme was used to distinguish between D614 from G614 as the former nucleic acid sequence is cleaved but the latter remains uncut (Figure 2A). Therefore, PCR products, amplified by D614G Out primers, were incubated with $\mathrm{BtsCl}$ restriction endonuclease at $50^{\circ} \mathrm{C}$ for 30 minutes in $\mathrm{BtsCl}$ buffer and inactivated at $80^{\circ} \mathrm{C}$ for 20 minutes as recommended by the manufacturer (New England Biolabs, Ipswich, MA, USA). 
medRxiv preprint doi: https://doi.org/10.1101/2021.04.12.21255337; this version posted April 19, 2021. The copyright holder for this preprint (which was not certified by peer review) is the author/funder, who has granted medRxiv a license to display the preprint in perpetuity.

It is made available under a CC-BY-NC 4.0 International license.

Furthermore, to confirm the action of the enzyme, a positive control was exploited by amplifying a human cytochrome b gene using universal primers (Kocher et al., 1989) since its DNA sequence contains BtsCl restriction site ( $5^{\prime}$...NNCATCC...3') using the NEB cutter as shown in Figure 2B.

\subsubsection{DNA sequencings}

Three (3) PCR products, amplified by conventional RT PCR using D614G Out primers, were randomly sent for Sanger sequencings (Macrogen Co., Seoul, KR), to confirm D614G mutants and the sequences were submitted to NCBI using Bankit (Benson et al., 2015).

\section{Results}

The current study has developed three methods including probe-based rRT PCR, ARMS and RFLP. For the first time, using fast, cost-effective methods, this study has identified G614 mutants in 67 nasopharyngeal samples in Iraq.

\subsection{Probe-based rRT PCR:}

In the primer-probe rRT PCR method, two primers (D614G IN forward and reverse) with two probes (D-FAM and G-HEX) were designed for detecting D614 and G614 variants of SARS CoV2 , respectively. The probes and primers worked in $250 \mathrm{nM}$ final concentrations at $61^{\circ} \mathrm{C}$ as shown in Figure 3.

\subsection{ARMS PCR:}

The single plex reactions (Panel A) performed for D614 AF and Out R primers showed no PCR products (Figure 4-A-1) that indicates wild type D614 variant is lacking. The second single plex reaction performed using G614 GR and Out F primers, a PCR product of approximately 176 bp indicates G614 mutant (Figure 4-A-2). The third single plex reaction shows PCR products (266 bp) using Out F and Out R primers confirmed that the outer primers worked (Figure 4-A3). Multiplex ARMS PCR, using all primers in a single tube (Panel B), shows two PCR products with sizes of $176 \mathrm{bp}$ and $266 \mathrm{bp}$, which indicated G614 mutant and outer PCR products, respectively. The results of ARMS PCR have corresponded with the rRT PCR data.

\subsection{RFLP}

Incubations of PCR products, amplified by D614G Out primers, with BtsCl enzyme, produced no cleavages indicated that only G614 mutants of SARS CoV-2 are prevalent in the region. The 
medRxiv preprint doi: https://doi.org/10.1101/2021.04.12.21255337; this version posted April 19, 2021. The copyright holder for this preprint (which was not certified by peer review) is the author/funder, who has granted medRxiv a license to display the preprint in perpetuity.

It is made available under a CC-BY-NC 4.0 International license.

enzyme validity was checked by incubations with human cytochrome b PCR products amplified by universal primers as described in section 2.4.3. The results showed that the $\mathrm{BtsCl}$ enzyme has cleaved the PCR products of the human cytochrome b (Figure 5).

\subsection{DNA squences}

The DNA sequences results showed only G614 variants as Genbank accession numbers (MW405786, MW405787 and $\underline{\text { MW405788) }}$ were released in NCBI online data base.

\section{Discussions}

In the current study, we developed three rapid and inexpensive techniques that can be used to discriminate between D614 and G614 variants. The methods included rRT PCR, ARMS and RFLP. Data obtained by these methods revealed that only G614 mutants are prevalent in the studied region. The results of all of the three methods are corresponding with each other and the DNA sequencing data. We believe our methods are advantageous over SARS CoV-2 whole genome sequences, particularly in developing countries for tracking the D614G mutation and its association with severity, infectivity, and fatality which have been controversial in various studies. It is worth to remember the origin of the virus has not been found. However, WHO has been searching for the viral emergence in Wuhan suggested that the virus may have been arisen from frozen wildlife or SARS CoV-2 related viruses of animals circulated outside China (Wacharapluesadee et al., 2021). The first SARS CoV-2 cases form Wuhan China were considered as an original wild type D614. Thus, future re-emergence of the D614 is not unlikely. Therefore, reasonable diagnostic techniques are required for discovering future D614 outbreaks or tracking previous retro-perspective samples preserved in developing countries. For example in Iraq, a whole genome sequencing has been performed for one sample concluding for discovering G614 mutation that may help understanding the spread of the virus (Al-Rashedi et al., 2021). Therefore, retro-perspective studies for hunting both D614 and G614 are an area of interest in developing countries.

Previous in vitro and simulation studies have found that G614 mutation is considered as more infectious variant than the D614 wildtype (Daniloski et al., 2020; Hou et al., 2020; Hu et al., 2020; Korber et al., 2020; Li et al., 2020; Wang et al., 2020). Studies showed that D614G mutation is associated with antigenic epitopes (Gupta et al., 2020; Hernández-Huerta et al., 2020; Islam et al., 2020; Kim et al., 2020; Koyama et al., 2020; Saha et al., 2020; To et al., 
medRxiv preprint doi: https://doi.org/10.1101/2021.04.12.21255337; this version posted April 19, 2021. The copyright holder for this preprint (which was not certified by peer review) is the author/funder, who has granted medRxiv a license to display the preprint in perpetuity. It is made available under a CC-BY-NC 4.0 International license .

2020), antibody neutralizing sensitivity (Goldman et al., 2020; Hu et al., 2020; Klumpp-Thomas et al., 2020; Li et al., 2020; Mansbach et al., 2020), infectivity (Daniloski et al., 2020; van Dorp et al., 2020; Hu et al., 2020; Korber et al., 2020; Li et al., 2020), transmission (van Dorp et al., 2020) and fatality (Hernández-Huerta et al., 2020). Plante et al 2020 have suggested that SARS CoV-2 G614 variant has roles in increasing upper respiratory viral loads, transmissions and survival fitness of the virus (Plante et al., 2020). To explore whether this SNV was as a result of either founder effects or viral fitness, caused by random mutation in the viral genome, larger clinical data could be linked with this SNV by comparing SARS CoV-2 disease severity with each $\mathrm{D} 614$ or $\mathrm{G} 614$ subtypes.

The global vaccines against SARS CoV-2 have been designed using the wildtype D614 virus. One of the most problematic features, which play roles in succeeding vaccines and monoclonal antibodies, is viral SNVs that make the virus resist neutralizing antibodies produced by the vaccines or immune-therapeutics. Therefore, some vaccines or designed antibodies may not be effective against all SARS CoV-2 variants. Thus, identifications of SARS CoV-2 SNVs may help researchers to examine vaccination programs and immunological drugs (Fernández, 2020a, 2020b), before vaccine or drug trial steps.

There have been controversies around the impacts of D614G mutations on vaccine developments. For instance, in a study that used both in vitro experiments and structural modelling, G614 has been shown to have no effects on vaccines (McAuley et al., 2020). However, it has been revealed that SARS CoV-2 mutations impact the viral spike antigenic epitopes which are normally recognized and neutralized by antibodies produced by Blymphocytes (Fernández, 2020b).

A limitation of this study was the absence of the D614 wild type subtype in the area where SARS CoV-2 has been spreading. However, in our study, three assays, as Taqman probes, ARMS, and RFLP all validated each other, in addition to the DNA sequencing data.

Co-segregations of SNVs are also essential for future understanding of the roles of viral pathogenesis and host immune responses against the virus. For instance, identifications of common co-occurred mutations in SARS CoV-2 spike proteins at a particular population would overcome problems of the viral antibody resistance and host cell binding capacity of the virus. By 12 February 2021, the D614G (A23403G) is the most prevalent single nucleotide variations (SNVs) in the world that is about 439,559 sequences (95.5\%). Other common mutations in the 
medRxiv preprint doi: https://doi.org/10.1101/2021.04.12.21255337; this version posted April 19, 2021. The copyright holder for this preprint (which was not certified by peer review) is the author/funder, who has granted medRxiv a license to display the preprint in perpetuity. It is made available under a CC-BY-NC 4.0 International license .

spike (S) protein, including A222V (C22227T), L81S (C21614T), and S477N (G22992A), are cooccurred with D614G in 100,401 sequences (21.8\%), 45,943 sequences (10\%) and 23,426 sequences (5.1\%), respectively (Covid19 CG data: https://covidcg.org/?tab=group). Moreover, a UK variant, N501Y, has been emerged since October 2020 and currently spreading in the country (Leung et al., 2021) and has become public threat in more than 30 countries (WHO, 2020). Therefore, future work should concentrate on these four mutations to see whether their co-occurrences with D614G are associated with disease severity, infectivity, transmissions, and antibody sensitivity.

Moreover, mutations play roles in zoonotic transmissions from animals to humans and vice versa. A recent study has shown that mammals such as mink harbour SARS CoV-2 mutations, which make the virus resistant to neutralizing antibodies from recovered patients (Oude Munnink et al., 2020). However, minks have naturally infected with both D614 and G614 variants of SARS CoV-2, no evidence shows the impact of G614 mutations in zoonotic outbreaks in this species of mammals. Nonetheless, this suggests that mink and other mammals could have been reservoirs for both D614 and G614 variants that their outbreaks might occur in future. Further studies using large numbers of samples are necessary to discover this effect. Besides, re-infections with SARS CoV-2 are also rare in the world (Goldman et al., 2020; To et al., 2020) and it is also essential to study the roles of mutations including G614 variants in re-infections. Rapid and cost-effective methods are also essential to study the roles of mutations in zoonosis, animals reservoirs and re-infections.

\section{Conclusions}

Up to our best knowledge, this is the first assay developed specifically for exploring SARS CoV2 D614G mutation using specific primers and probes for detecting D614G mutant by using real-time, conventional PCR and restriction endonuclease. This will help developing countries to conduct further research on this mutation concerning the origin of the virus using previously preserved samples and re-infections occurred between the pandemic waves. Future research should focus on other common co-segregated mutations occurred SARS CoV2 genome.

\section{Acknowledgements}


medRxiv preprint doi: https://doi.org/10.1101/2021.04.12.21255337; this version posted April 19, 2021. The copyright holder for this preprint (which was not certified by peer review) is the author/funder, who has granted medRxiv a license to display the preprint in perpetuity.

It is made available under a CC-BY-NC 4.0 International license .

We would like to thank Sheikh Hassan Al-Talabani for his great support building our new laboratory, Coronavirus Research and Identification Lab., amid Covid-19 becoming pandemic.

\section{Authors statements}

Conceptualization: SMAA, and SSN; Data curation: SMAA, and SSN; Formal analysis SMAA, and SSN; Investigation: all authors; Methodology: SMAA, and SSN; Resources: all authors; Validation: SMAA, and SSN; Visualization: SMAA, and SSN; Writing - original draft: SMAA, and SSN; Writing - review \& editing: all authors.

\section{References}

Ahmadpour D, Ahmadpoor P, Rostaing L. Impact of Circulating SARS-CoV-2 Mutant G614 on the COVID-19 Pandemic. Iran J Kidney Dis 2020;14:331-4.

Al-Rashedi NAM, Licastro D, Rajasekharan S, Dal Monego S, Marcello A, Munahi MG, et al. Genome Sequencing of a Novel Coronavirus SARS-CoV-2 Isolate from Iraq. Microbiol Resour Announc 2021;10. https://doi.org/10.1128/MRA.01316-20.

Badua CLDC, Baldo KAT, Medina PMB. Genomic and proteomic mutation landscapes of SARS-CoV-2. J Med Virol 2020;n/a. https://doi.org/10.1002/jmv.26548.

Benson DA, Clark K, Karsch-Mizrachi I, Lipman DJ, Ostell J, Sayers EW. GenBank. Nucleic Acids Res 2015;43:D30-5. https://doi.org/10.1093/nar/gku1216.

Bhattacharyya C, Das C, Ghosh A, Singh AK, Mukherjee S, Majumder PP, et al. Global Spread of SARS-CoV-2 Subtype with Spike Protein Mutation D614G is Shaped by Human Genomic Variations that Regulate Expression of TMPRSS2 and MX1 Genes. BioRxiv 2020.

Daniloski Z, Guo X, Sanjana NE. The D614G mutation in SARS-CoV-2 Spike increases transduction of multiple human cell types. BioRxiv Prepr Serv Biol 2020:2020.06.14.151357. https://doi.org/10.1101/2020.06.14.151357.

Dearlove B, Lewitus E, Bai H, Li Y, Reeves DB, Joyce MG, et al. A SARS-CoV-2 vaccine candidate would likely match all currently circulating variants. Proc Natl Acad Sci 2020;117:23652 LP - 23662. https://doi.org/10.1073/pnas.2008281117.

van Dorp L, Richard D, Tan CCS, Shaw LP, Acman M, Balloux F. No evidence for increased transmissibility from recurrent mutations in SARS-CoV-2. BioRxiv 2020:2020.05.21.108506. 
medRxiv preprint doi: https://doi.org/10.1101/2021.04.12.21255337; this version posted April 19, 2021. The copyright holder for this preprint (which was not certified by peer review) is the author/funder, who has granted medRxiv a license to display the preprint in perpetuity. It is made available under a CC-BY-NC 4.0 International license .

https://doi.org/10.1101/2020.05.21.108506.

Fernández A. Therapeutically Targeted Destabilization of the Quaternary Structure of the Spike Protein in the Dominant G614 Strain of SARS-CoV-2. ACS Pharmacol Transl Sci 2020a;3:1027-9. https://doi.org/10.1021/acsptsci.0c00114.

Fernández A. Structural Impact of Mutation D614G in SARS-CoV-2 Spike Protein: Enhanced Infectivity and Therapeutic Opportunity. ACS Med Chem Lett 2020b;11:1667-70. https://doi.org/10.1021/acsmedchemlett.0c00410.

Garcia-Beltran WF, Lam EC, Astudillo MG, Yang D, Miller TE, Feldman J, et al. COVID-19 neutralizing antibodies predict disease severity and survival. MedRxiv 2020:2020.10.15.20213512. https://doi.org/10.1101/2020.10.15.20213512.

Goldman JD, Wang K, Roltgen K, Nielsen SCA, Roach JC, Naccache SN, et al. Reinfection with SARS-CoV-2 and Failure of Humoral Immunity: a case report. MedRxiv Prepr Serv Heal Sci 2020:2020.09.22.20192443. https://doi.org/10.1101/2020.09.22.20192443.

Gómez-Carballa A, Bello X, Pardo-Seco J, Pérez Del Molino ML, Martinón-Torres F, Salas A. Phylogeography of SARS-CoV-2 pandemic in Spain: a story of multiple introductions, microgeographic stratification, founder effects, and super-spreaders. Zool Res 2020:1-16. https://doi.org/10.24272/j.issn.2095-8137.2020.217.

Grubaugh ND, Hanage WP, Rasmussen AL. Making Sense of Mutation: What D614G Means for the COVID-19 Pandemic Remains Unclear. Cell 2020;182:794-5. https://doi.org/10.1016/j.cell.2020.06.040.

Gupta AM, Chakrabarti J, Mandal S. Non-synonymous mutations of SARS-CoV-2 leads epitope loss and segregates its variants. Microbes Infect 2020. https://doi.org/https://doi.org/10.1016/j.micinf.2020.10.004.

Hashemi SA, Khoshi A, Ghasemzadeh-Moghaddam H, Ghafouri M, Taghavi M, NamdarAhmadabad H, et al. Development of a PCR-RFLP method for detection of D614G mutation in SARS-CoV-2. Infect Genet Evol J Mol Epidemiol Evol Genet Infect Dis 2020;86:104625. https://doi.org/10.1016/j.meegid.2020.104625.

Hernández-Huerta MT, Mayoral LP-C, Díaz CR, Cruz MM, Mayoral-Andrade G, Navarro LMS, et al. Analysis of SARS-CoV-2 mutations in Mexico, Belize and isolated regions of Guatemala 
medRxiv preprint doi: https://doi.org/10.1101/2021.04.12.21255337; this version posted April 19, 2021. The copyright holder for this preprint (which was not certified by peer review) is the author/funder, who has granted medRxiv a license to display the preprint in perpetuity.

It is made available under a CC-BY-NC 4.0 International license .

and its implication in the diagnosis. J Med Virol 2020;n/a.

https://doi.org/10.1002/jmv.26591.

Hou YJ, Chiba S, Halfmann P, Ehre C, Kuroda M, Dinnon KH, et al. SARS-CoV-2 D614G Variant Exhibits Enhanced Replication ex vivo and Earlier Transmission in vivo. BioRxiv Prepr Serv Biol 2020:2020.09.28.317685. https://doi.org/10.1101/2020.09.28.317685.

Hu J, He C-L, Gao Q-Z, Zhang G-J, Cao X-X, Long Q-X, et al. The D614G mutation of SARS-CoV2 spike protein enhances viral infectivity and decreases neutralization sensitivity to individual convalescent sera. BioRxiv 2020:2020.06.20.161323.

https://doi.org/10.1101/2020.06.20.161323.

Isabel S, Graña-Miraglia L, Gutierrez JM, Bundalovic-Torma C, Groves HE, Isabel MR, et al. Evolutionary and structural analyses of SARS-CoV-2 D614G spike protein mutation now documented worldwide. Sci Rep 2020;10:14031. https://doi.org/10.1038/s41598-02070827-z.

Islam OK, Al-Emran HM, Hasan MS, Anwar A, Jahid MIK, Hossain MA. Emergence of European and North American mutant variants of SARS-CoV-2 in South-East Asia. Transbound Emerg Dis 2020;n/a. https://doi.org/10.1111/tbed.13748.

Kim S-J, Nguyen V-G, Park Y-H, Park B-K, Chung H-C. A Novel Synonymous Mutation of SARSCoV-2: Is This Possible to Affect Their Antigenicity and Immunogenicity? Vaccines 2020;8:220. https://doi.org/10.3390/vaccines8020220.

Klumpp-Thomas C, Kalish H, Hicks J, Mehalko J, Drew M, Memoli MJ, et al. D614G Spike Variant Does Not Alter IgG, IgM, or IgA Spike Seroassay Performance. MedRxiv Prepr Serv Heal Sci 2020:2020.07.08.20147371. https://doi.org/10.1101/2020.07.08.20147371.

Kocher TD, Thomas WK, Meyer A, Edwards S V, Pääbo S, Villablanca FX, et al. Dynamics of mitochondrial DNA evolution in animals: amplification and sequencing with conserved primers. Proc Natl Acad Sci U S A 1989;86:6196-200.

https://doi.org/10.1073/pnas.86.16.6196.

Korber B, Fischer WM, Gnanakaran S, Yoon H, Theiler J, Abfalterer W, et al. Tracking Changes in SARS-CoV-2 Spike: Evidence that D614G Increases Infectivity of the COVID-19 Virus. Cell 2020;182:812-827.e19. 
medRxiv preprint doi: https://doi.org/10.1101/2021.04.12.21255337; this version posted April 19, 2021. The copyright holder for this preprint (which was not certified by peer review) is the author/funder, who has granted medRxiv a license to display the preprint in perpetuity. It is made available under a CC-BY-NC 4.0 International license .

https://doi.org/https://doi.org/10.1016/j.cell.2020.06.043.

Koyama T, Weeraratne D, Snowdon JL, Parida L. Emergence of Drift Variants That May Affect COVID-19 Vaccine Development and Antibody Treatment. Pathog (Basel, Switzerland) 2020;9. https://doi.org/10.3390/pathogens9050324.

Leung K, Shum MH, Leung GM, Lam TT, Wu JT. Early transmissibility assessment of the N501Y mutant strains of SARS-CoV-2 in the United Kingdom, October to November 2020. Euro Surveill Bull Eur Sur Les Mal Transm = Eur Commun Dis Bull 2021;26. https://doi.org/10.2807/1560-7917.ES.2020.26.1.2002106.

Li Q, Wu J, Nie J, Zhang Li, Hao H, Liu S, et al. The Impact of Mutations in SARS-CoV-2 Spike on Viral Infectivity and Antigenicity. Cell 2020;182:1284-1294.e9.

https://doi.org/10.1016/j.cell.2020.07.012.

Mansbach RA, Chakraborty S, Nguyen K, Montefiori D, Korber B, Gnanakaran S. The SARSCoV-2 Spike Variant D614G Favors an Open Conformational State. BioRxiv Prepr Serv Biol 2020:2020.07.26.219741. https://doi.org/10.1101/2020.07.26.219741.

McAuley AJ, Kuiper MJ, Durr PA, Bruce MP, Barr J, Todd S, et al. Experimental and in silico evidence suggests vaccines are unlikely to be affected by D614G mutation in SARS-CoV-2 spike protein. NPJ Vaccines 2020;5:96. https://doi.org/10.1038/s41541-020-00246-8.

Niranji SS, Al-Jaf SMA. Comments on "Development of a PCR-RFLP method for detection of D614G mutation in SARS-CoV-2". Infect Genet Evol J Mol Epidemiol Evol Genet Infect Dis 2021;87:104661. https://doi.org/10.1016/j.meegid.2020.104661.

Omotuyi IO, Nash O, Ajiboye OB, Iwegbulam CG, Oyinloye EB, Oyedeji OA, et al. Atomistic simulation reveals structural mechanisms underlying D614G spike glycoprotein-enhanced fitness in SARS-COV-2. J Comput Chem 2020;41:2158-61.

https://doi.org/10.1002/jcc.26383.

Oude Munnink BB, Sikkema RS, Nieuwenhuijse DF, Molenaar RJ, Munger E, Molenkamp R, et al. Transmission of SARS-CoV-2 on mink farms between humans and mink and back to humans. Science 2020. https://doi.org/10.1126/science.abe5901.

Pachetti M, Marini B, Benedetti F, Giudici F, Mauro E, Storici P, et al. Emerging SARS-CoV-2 mutation hot spots include a novel RNA-dependent-RNA polymerase variant. J Transl Med 
medRxiv preprint doi: https://doi.org/10.1101/2021.04.12.21255337; this version posted April 19, 2021. The copyright holder for this preprint (which was not certified by peer review) is the author/funder, who has granted medRxiv a license to display the preprint in perpetuity.

It is made available under a CC-BY-NC 4.0 International license .

2020;18:179. https://doi.org/10.1186/s12967-020-02344-6.

Phan T. Genetic diversity and evolution of SARS-CoV-2. Infect Genet Evol 2020;81:104260. https://doi.org/10.1016/j.meegid.2020.104260.

Plante JA, Liu Y, Liu J, Xia H, Johnson BA, Lokugamage KG, et al. Spike mutation D614G alters SARS-CoV-2 fitness. Nature 2020. https://doi.org/10.1038/s41586-020-2895-3.

Robson F, Khan KS, Le TK, Paris C, Demirbag S, Barfuss P, et al. Coronavirus RNA Proofreading: Molecular Basis and Therapeutic Targeting. Mol Cell 2020;79:710-27. https://doi.org/https://doi.org/10.1016/j.molcel.2020.07.027.

Romano M, Ruggiero A, Squeglia F, Maga G, Berisio R. A Structural View of SARS-CoV-2 RNA Replication Machinery: RNA Synthesis, Proofreading and Final Capping. Cells 2020;9:1267. https://doi.org/10.3390/cells9051267.

Saha P, Majumder R, Chakraborty S, Kumar A. Mutations in Spike protein of SARS-CoV-2 modulate receptor binding, membrane fusion and immunogenicity: an insight into viral tropism and pathogenesis of COVID-19 2020.

To KK-W, Hung IF-N, Ip JD, Chu AW-H, Chan W-M, Tam AR, et al. COVID-19 re-infection by a phylogenetically distinct SARS-coronavirus-2 strain confirmed by whole genome sequencing. Clin Infect Dis an Off Publ Infect Dis Soc Am 2020. https://doi.org/10.1093/cid/ciaa1275.

Wacharapluesadee S, Tan CW, Maneeorn P, Duengkae P, Zhu F, Joyjinda Y, et al. Evidence for SARS-CoV-2 related coronaviruses circulating in bats and pangolins in Southeast Asia. Nat Commun 2021;12:972. https://doi.org/10.1038/s41467-021-21240-1.

Walls AC, Park Y-J, Tortorici MA, Wall A, McGuire AT, Veesler D. Structure, Function, and Antigenicity of the SARS-CoV-2 Spike Glycoprotein. Cell 2020;181:281-292.e6. https://doi.org/10.1016/j.cell.2020.02.058.

Wang B, Asarnow D, Lee W-H, Huang C-W, Faust B, Ng PML, et al. Bivalent binding of a fully human IgG to the SARS-CoV-2 spike proteins reveals mechanisms of potent neutralization. BioRxiv Prepr Serv Biol 2020:2020.07.14.203414. https://doi.org/10.1101/2020.07.14.203414.

WHO. SARS-CoV-2 Variants 2020. https://www.who.int/csr/don/31-december-2020-sars- 
medRxiv preprint doi: https://doi.org/10.1101/2021.04.12.21255337; this version posted April 19, 2021. The copyright holder for this preprint (which was not certified by peer review) is the author/funder, who has granted medRxiv a license to display the preprint in perpetuity.

It is made available under a CC-BY-NC 4.0 International license.

cov2-variants/en/ (accessed January 15, 2021).

Xu W, Wang M, Yu D, Zhang X. Variations in SARS-CoV-2 Spike Protein Cell Epitopes and Glycosylation Profiles During Global Transmission Course of COVID-19. Front Immunol 2020;11:565278. https://doi.org/10.3389/fimmu.2020.565278.

Yurkovetskiy L, Wang X, Pascal KE, Tomkins-Tinch C, Nyalile TP, Wang Y, et al. Structural and Functional Analysis of the D614G SARS-CoV-2 Spike Protein Variant. Cell 2020.

https://doi.org/https://doi.org/10.1016/j.cell.2020.09.032.

Zhang L, Jackson CB, Mou H, Ojha A, Rangarajan ES, Izard T, et al. The D614G mutation in the SARS-CoV-2 spike protein reduces S1 shedding and increases infectivity. BioRxiv Prepr Serv Biol 2020:2020.06.12.148726. https://doi.org/10.1101/2020.06.12.148726.

Zhang Yong, Pan Y, Zhao X, Shi W, Chen Z, Zhang S, et al. Genomic characterization of SARSCoV-2 identified in a reemerging COVID-19 outbreak in Beijing's Xinfadi market in 2020. Biosaf Heal 2020. https://doi.org/https://doi.org/10.1016/j.bsheal.2020.08.006.

Zhang Yang, Xi H, Juhas M. Biosensing Detection of the SARS-CoV-2 D614G Mutation. Trends Genet 2020. https://doi.org/10.1016/j.tig.2020.12.004.

Table 1: Primers and probes for rRT PCR, ARMS and RFLP

\begin{tabular}{l|l|l|l}
\hline Primers & Sequence & TM & GC $\%$ \\
\hline D614G In F & GAGATTCTTGACATTACACCATG & 59 & 39 \\
\hline D614G In R & CTGTAGAATAAACACGCCAAG & 59 & 43 \\
\hline D614 D-FAM & FAM- TTCTTTATCAGGATGTTAACTGCACAG-BHQ1 & 64 & 37 \\
\hline G614 G-HEX & HEX-TTCTTTATCAGGGTGTTAACTGCACAG-BHQ2 & 65 & 41 \\
\hline D614G Out F & AACAATTTGGCAGAGACATTG & 60 & 38 \\
\hline D614G Out R & CTATTAAACAGCCTGCACGT & 60 & 45 \\
\hline D614 ARMS mis A F & CAGGTTGCTGTTCTTATCAaGA & 57 & 39 \\
\hline G614 ARMS mis G R & AGGGACTTCTGTGCAGTTAAtAC & 58 & 43 \\
\hline
\end{tabular}


medRxiv preprint doi: https://doi.org/10.1101/2021.04.12.21255337; this version posted April 19, 2021. The copyright holder for this preprint (which was not certified by peer review) is the author/funder, who has granted medRxiv a license to display the preprint in perpetuity.

It is made available under a CC-BY-NC 4.0 International license .

A) A part of amino acid sequences of D614

RVVVLSFELLHAPATVCGPKKSTNLVKNKCVNFNFNGLTGTGVLTESNKKFLPFQQFG RDIADTTDAVRDPQTLEILDITPCSFGGVSVITPGTNTSNQVAVLYQDVNCTEVPVAI HADQLTPTWRVYSTGSNVFQTRAGCLIGAEHVNNSYECDIPIGAGICASYQTQTNSPR

Wild type: GAT is codon for $\underline{\mathrm{D}} 614$ (Aspartate) $=\mathrm{A} 23403$

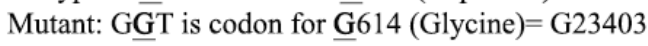

B) rRT PCR

D614G In F

23281 tgatgctgtc cgtgatccac agacacttga gattcttgac attacaccat gttctttgg

23341 tggtgtcagt gttataacac caggaacaaa tacttctaac caggttgctg ttctttatca

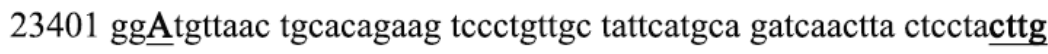
$\underline{\mathrm{G}}$

D614G In R

23461 gcgtgtttat tctacaggtt ctaatgtttt tcaaacacgt gcaggctgtt taataggggc

D614 FAM: FAM- TTCTTTATCAGGATGTTAACTGCACAG- BHQ1 G614 HEX: HEX- TTCTTTATCAGGGTGTTAACTGCACAG- BHQ2

C) ARMS-PCR

D614G Out F

23221 tgagtctaac aaaaagtttc tgcctttcca acaatttgge agagacattg ctgacactac

23281 tgatgetgtc cgtgatccac agacacttga gattcttgac attacaccat gttctttgg

D614 ARMS mis A F

23341 tggtgtcagt gttataacac caggaacaaa tacttctaac caggttgetg ttctttatca

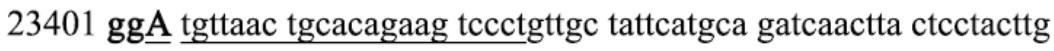

G G614 ARMS mis G R

D614G Out R

23461 gcgtgtttat tctacaggtt ctaatgtttt tcaaacacgt gcaggctgtt taataggggc

D614= D614 ARMS mis A F VS D614G Out $\mathrm{R}=134 \mathrm{bp}$

G614= G614 ARMS mis G R VS D614G Out F=176 bP

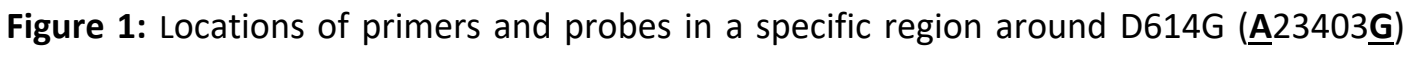
mutation in SARS CoV-2 isolate Wuhan-Hu-1, complete genome. GenBank: MN908947.3. A part of amino acid sequences showing amino acid D614 which is mutated to G614 (A). Locations of rRT PCR Primers and probes (B). Locations of ARMS PCR primers (C). 
medRxiv preprint doi: https://doi.org/10.1101/2021.04.12.21255337; this version posted April 19, 2021. The copyright holder for this preprint (which was not certified by peer review) is the author/funder, who has granted medRxiv a license to display the preprint in perpetuity.

It is made available under a CC-BY-NC 4.0 International license .

A)

D614G out F Primer

23221 tgagtctaac aaaagtttc tgccttcca acaatttggc agagacattg ctgacactac

23281 tgatgctgtc cgtgatccac agacacttga gattcttgac attacaccat gttctttgg

23341 tggtgtcagt gttataacac caggaacaaa tacttctaac caggttgctg ttctttatca

BtsCI restriction site

5'...GGATGNN... 3'

D614 23401 ggatgttaac tgcacagaag tccctgttgc tattcatgca gatcaactta ctcctacttg

G614 23401 gggtgttaac tgcacagaag tccctgttgc tattcatgca gatcaactta ctcctacttg

23461 gcgtgtttat tctacaggtt ctaatgtttt tcaaacacgt gcaggctgtt taataggggc

D614G out R Primer

B)

Cytob F Primer

1 ccatccaaca tctcagcatg atgaaacttc ggctcactcc ttggcgcetg cetgatcctc

61 caatcacca caggactatt cctagccatg cactactcac cagacgcctc aaccgcctt

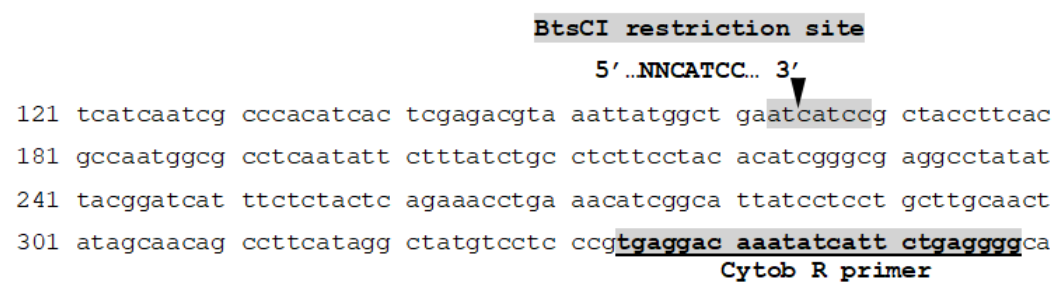

Figure 2: DNA sequencings of both SARS CoV-2 D614G and human cytochrome $b$ used for RFLP: Panel (A) Nucleic acid sequences of SARS CoV-2 shows restriction site (GGATGNN) in the wild type D614 which is cleaved by $\mathrm{BtsCl}$ enzyme while $\mathrm{G} 614$ mutant sequence is not cut by the enzyme. Both D614G Out $F$ and $R$ primers are also located. Panel $B$ ) Nucleic acid sequences of human cytochrome $b$ gene shows restriction site $\left(5^{\prime}\right.$...NNCATCC... $\left.3^{\prime}\right)$ which is cleaved by $\mathrm{Bts} \mathrm{Cl}$ enzyme. Both universal $\mathrm{F}$ and $\mathrm{R}$ primers are also located.

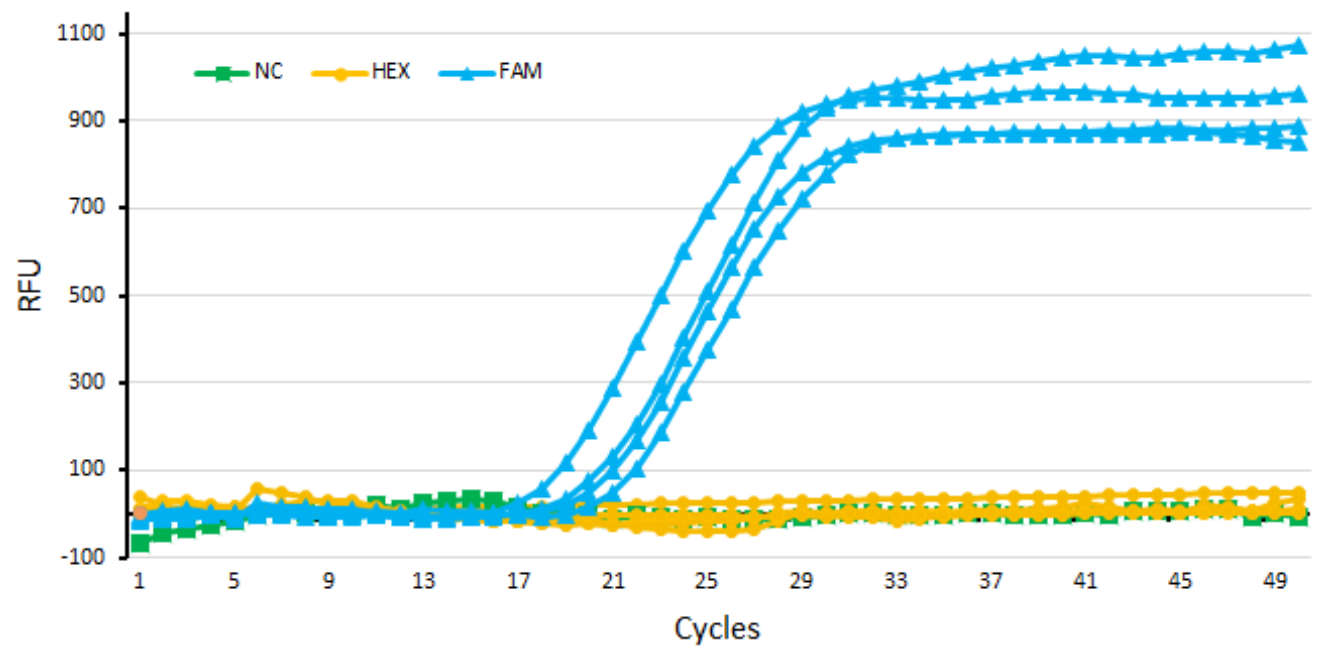

Figure 3: Amplification curves using AddProbe rRT PCR master mix (AddBio) using D614G IN primers and probes including D614 D-FAM and G614 G-HEX probes. Only HEX (blue) showed amplification curves indicating the G614 mutant, but FAM (yellow) did not form amplification curves indicating that wild type D614 is absent. NC (green) is a negative control. 

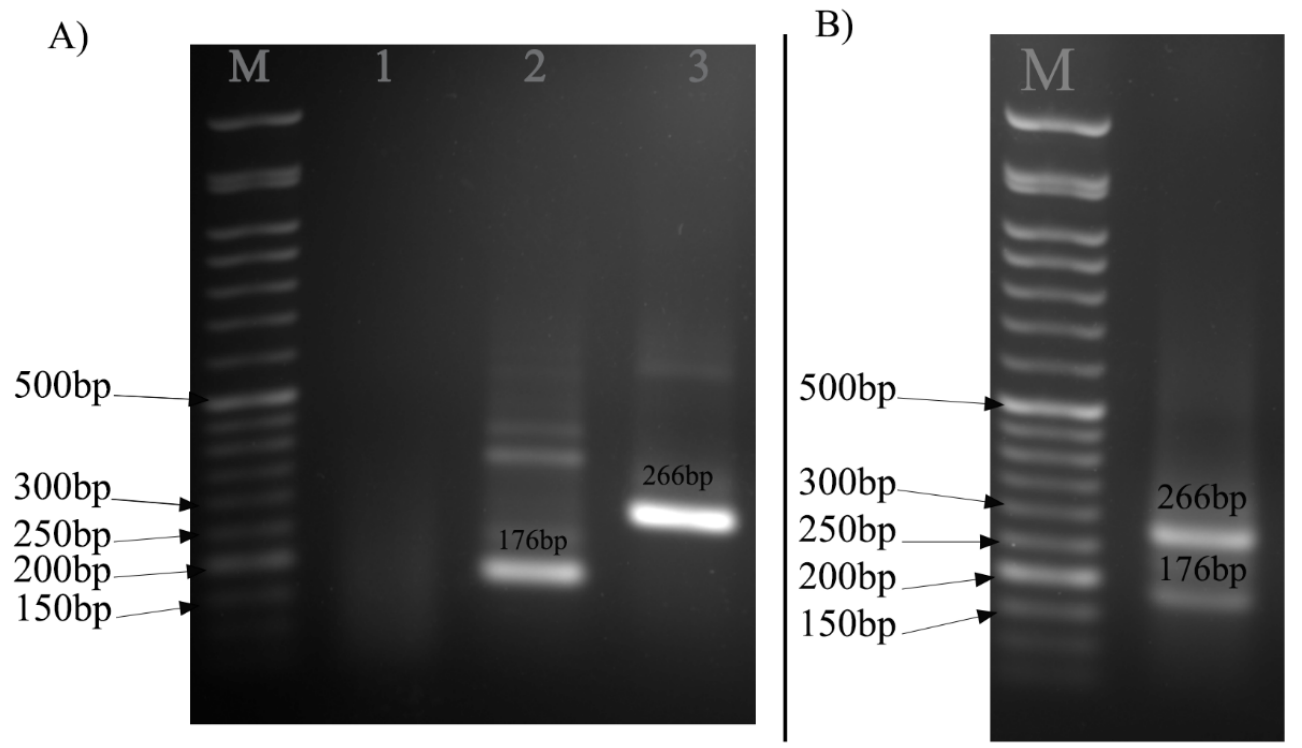

Figure 4: PCR products on 1.5\% agarose gel electrophoresis: Addscript RT PCR master mix (AddBio) using ARMS PCR primers. Panel A: PCR products using primers separately. Well 1: PCR products using D614 AF and Out R primes. Well 2: PCR products using G614 GR and Out F primers generating $176 \mathrm{bp}$. Well 3: PCR products using Out F and Out R primers creating $266 \mathrm{bp}$. Panel B: an example of a PCR Product using all primers D614 AF, G614 GR, Out F and Out $\mathrm{R}$ in a single tube reaction that created 176 bp (for G614 mutant) and 266 bp (for outer primers).

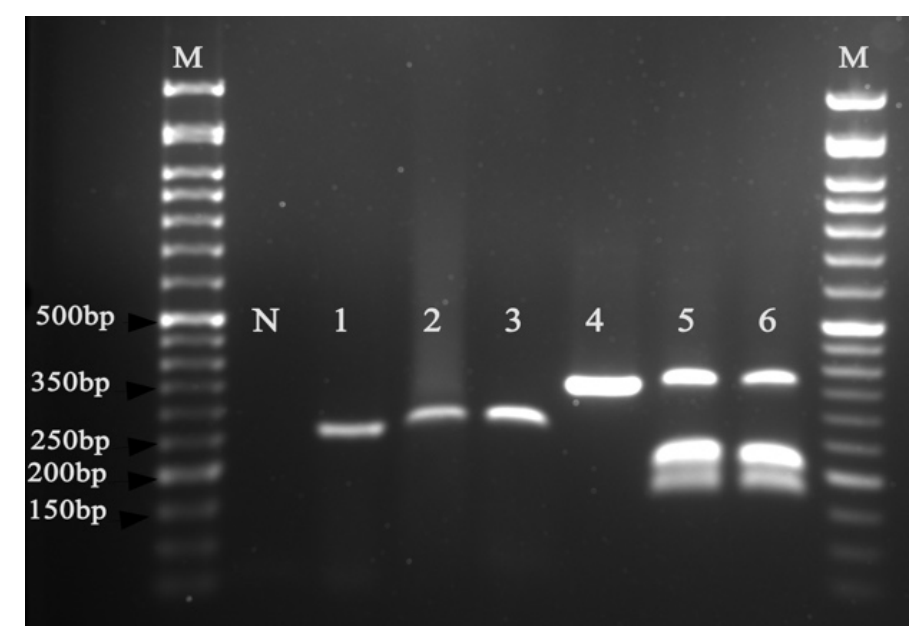

Figure 5: PCR products on 1.5\% agarose gel electrophoresis using Addscript RT PCR Master mix (AddBio) and ARMS PCR primers. $\mathrm{M}=$ DNA marker 50bp. $\mathrm{N}=$ negative control. Lane $1=$ undigested PCR product amplified by D614G Out primers. Lanes 2 and 3= PCR products amplified by D614G Out primers and incubated with $\mathrm{Bts} \mathrm{Cl}$ enzyme at $50^{\circ} \mathrm{C}$. Lane $4=$ undigested human cytochrome $b$ PCR products amplified by universal primers. Lanes 5 and $6=$ the human cytochrome $b$ PCR products were cleaved by the $\mathrm{Bts} \mathrm{Cl}$ enzyme. 